\title{
C-C Chemokine Receptor Type 9
}

National Cancer Institute

\section{Source}

National Cancer Institute. C-C Chemokine Receptor Type 9. NCI Thesaurus. Code C37457.

C-C chemokine receptor type 9 (369 aa, $\sim 42 \mathrm{kDa}$ ) is encoded by the human CCR9 gene. This protein is involved in chemokine-dependent G protein-coupled receptor signaling. 